СПб. : Питер, 2001. - 288 с. 2. Кричевский Р. Л. Психология малой группы: теоретический и прикладной аспекты / Р. Л. Кричевский, Е. М. Дубовская. - М. : Издво МГУ, 1991. - 207 с. З. Лийметс Х. Й. Групповая работа на уроке / Х. Й. Лийметс. М. :Знание, 1975. - 64 с. 4. Ложкін Г. Команда як колективний суб'єкт спільної діяльності / Григорій Ложкін // Соціальна психологія. - 2005. - № 5- С. 52-58. 5. Майерс Д. Социальная психология / David G. Myers; [перев с англ.]. -[2-е изд.]. Спб. : Питер, 1996. - 684 с. 6. Общение и оптимизация совместной деятельности /под ред. Г. Андреевой, Я. Яноушека. - М. : Изд-во МГУ, 1987. - 301 с. 7. Онищук В. О. Активізація навчання старшокласників / В. О. Онищук. - К. :Рад. школа, 1978. - 128 с. 8. Орбан-Лембрик Л. Е. Соціальна психологія :[підручник] : / Л. Е. ОрбанЛембрик. - К.: Либідь, 2006. - Кн. 2 : Соціальна психологія груп. Прикладна соціальна психологія. - 2006. - 560 с. 9. Ярошенко О. Г. Проблеми групової навчальної діяльності школярів: дидактико-методичний аспект:[монографія]/ О. Г. Ярошенко. - К. :Станіца, 1999. - 158 c. 10. Janis I. L. Groupthink: Psychological studies of policy decisions and fiascos (2nd ed.). - Boston: Houghton Mifflin, 1983. - 351 p.

Аліна Слюта

УДК 37.091.12:504+378.147.091.33-027.22

\title{
ПЕДАГОГІЧНІ УМОВИ ФОРМУВАННЯ ПРОФЕСІЙНИХ УМІНЬ СТУДЕНТІВ-ЕКОЛОГІВ У ПРОЦЕСІ ВИРОБНИЧОӤ ПРАКТИКИ ДЛЯ ЗАСТОСУВАННЯ ЇХ У МАЙБУТНІЙ ДІЯЛЬНОСТІ
}

Слюта А. М. Педагогічні умови формування професійних умінь студентівекологів у процесі виробничої практики для застосування їх у майбутній діяльності.

У статті узагальнено педагогічні умови формування професійних умінь студентів-екологів у процесі виробничої практики для застосування їх у майбутній діяльності. Автор наголошує на необхідності підвищення педагогічних вимог до якості професійної підготовки фахівців-екологів.

Ключові слова:професійні вміння, виробнича практика, студенти-екологи, професійна діяльність, професійна підготовка.

Слюта А. Н. Педагогические условия формирования профессиональных умений студентов-экологов в процессе производственной практики для применения их в будущей деятельности.

В статье обобщены педагогические условия формирования профессиональных умений студентов-экологов в процессе производственной практики для применения их в будущей профессиональной деятельности. Автор обращает внимание на необходимость повышения педагогических требований к качеству профессиональной подготовки специалистов-экологов.

Ключевые слова:профессиональные умения, производственная практика, студенты-экологи, профессиональная деятельность, профессиональная подготовка.

Slyuta A. N. Pedagogical conditions of professional skills to students of environmental practices in the production process for use in their future activity.

The paper summarizes the pedagogical conditions of professional skills to students of environmental practices in the production process for use in their future professional activity. The author draws attention to the need to improve the quality of pedagogical conditions of training of environmental specialists. 
Key words:professional skills, manufacturing practice, students-environmentalists, professional activity, professional training.

Соціальна потреба підготовки висококваліфікованих спеціалістів у галузі екології для сучасного виробництва висуває низку кваліфікаційних вимог до педагогічних працівників вищих навчальних закладів, які мають забезпечити таку підготовку кадрів, щоб задовольнити зазначену соціальну потребу. Пріоритетною зпоміж цих вимог $є$ необхідність реалізації інтегративної, професійної підготовки майбутніх фахівців-екологів, яка передбачала б системне поєднання практичних умінь i отриманих знань в процесі навчання в ході проходження ними виробничої практики.

Професійну підготовку еколога ми розглядаємо як процес оволодіння особистістю цінностями фахової діяльності, професійно необхідними знаннями, вміннями і навичками, які є основою готовності до професійної діяльності. Проблема виявлення умов, які ефективно забезпечують формування готовності людини до певної поведінки і діяльності, не втрачає своєї актуальності. У практиці вищої екологічної освіти вона становить інтерес для багатьох дослідників. Про це свідчать публікації [2; 4; 6].

Грунтуючись на аналізі наукової літератури, підготовку еколога до майбутньої професійної діяльності ми розуміємо як складний процес набуття і використання природничих, психолого-педагогічних і соціально-гуманітарних знань, формування цінностей, необхідних для розв'язання виробничих питань і творчого використання професійних умінь. Важливим результатом професійно-педагогічної підготовки майбутнього спеціаліста $є$ його готовність до застосування професійних умінь у майбутній професійній діяльності [4, с. 137-144].

У свою чергу, недостатність вивчення методичних орієнтирів щодо формування професійних умінь майбутніх фахівців на засадах виробничої практики спричинила одну 3 проблем дослідження - визначення сукупності педагогічних умов, що стимулюють формування у студентів-екологів професійних умінь у процесі проходження майбутніми фахівцямивиробничої практики.

Mema cmammi: узагальнити педагогічні умови формування професійних умінь студентів-екологів у процесі виробничої практики задля застосування їх у майбутній професійній діяльності.

Екологічна освіта у вищих навчальних закладах України, на думку М. Швед, здійснюється за двома основними напрямками - шляхом упровадження екологічних понять і проблем до змісту окремих дисциплін (екологізація змісту) та у процесі організації спеціальних екологічних курсів фахової підготовки [6]. Звернемо увагу саме на професійну, зокрема на підготовку фахівців-екологів у процесі проходження ними виробничої практики як невід'ємного компонента системи вищої освіти України.

Як зазначає С. Гончаренко [1, с. 275], професійна освіта $є$ результатом оволодіння певним рівнем знань, умінь і навичок діяльності з конкретного фаху. Отже, професійна підготовка є невід'ємним компонентом єдиної системи освіти, а іiї зміст передбачає поглиблене засвоєння основ та технологій виду праці, розвиток професійних навичок та вмінь, формування якостей особистості, важливих для роботи в обраній галузі.

Процес формування професійних умінь студентів-екологів відбувається тоді, коли ці вміння «працюють» у різних видах навчально-пізнавальної діяльності. Отже, формування професійних умінь може бути ефективнішим, якщо залучити студентів до навчально-пізнавальної діяльності як репродуктивного, так i проблемного, проблемно-пошукового і творчого характеру в їх поєднанні, 3 урахуванням поетапної системи навчання [2, с. 223-229]. 
Поняття «готовність» уміщує понад 40 компонентів, що свідчить про його багаторівневий характер. У психолого-педагогічних дослідженнях поняття розглядається як особистісне інтегральне утворення, яке включає мотивацію, психічні, моральні, професійні (практичні) особливості індивіда [3, с. 6].

На нашу думку, поняття «готовність» до професійної екологічної діяльності - це складне інтегративне утворення, єдність особистісних, індивідуально-психологічних якостей і систем професійних знань, умінь та навичок. Основними компонентами готовності $є$ мотиви, а саме: цінність діяльності, наявність професійних знань, володіння професійними вміннями і практичними навичками. Саме інтегральне взаємопов'язане і взаємозумовлене утворення цих компонентів і $є$ «готовністю».

Під педагогічними умовами ми розуміємо обставини, що забезпечують ефективне формування готовності студентів-екологів до застосування набутих знань у процесі навчання на практиці у майбутній діяльності. Такими є:

- сприяння позитивній мотивації студентів-екологів до майбутньої професійної діяльності;

- усвідомлення значущості професійних умінь для застосування їх у процесі професійної діяльності;

- орієнтування екологів на прийняття виробничих рішень у майбутній професійній діяльності;

- грунтовна практична підготовка майбутнього еколога на принципах міжпредметності, інтегративності, системності й узгодження задля формування системних знань про цілі, принципи, методи та засоби екологічної і природоохоронної діяльності на засадах парадигми сталого розвитку;

- реалізація вимог особистісно зорієнтованого навчання студента-еколога щодо його інтелектуальних інтересів та особистісних потреб, установок;

- реалізація потенціалу природничих та соціально-гуманітарних знань, оперування професійними вміннями;

- сприяння сформованості достатнього рівня емоційно-моральної культури і здатності до самовдосконалення, креативності, ініціативності;

- створення відносин співробітництва педагогів і студентів на основі взаємоповаги, взаєморозуміння й потреби у спільній пізнавальній діяльності;

- забезпечення можливостей вільного вибору студентами-екологами майбутнього місця (організації, підприємства, установи) для проходження виробничої практики, в тому числі з урахуванням теми дипломного проекту;

- забезпечення єдності основних компонентів підготовки студентів-екологів до застосування професійних умінь у майбутній професійній діяльності (мотиваційного, діяльнісного, особистісного, пізнавального, аксіологічного).

Отже, загальна схема педагогічних умов формування готовності студентівекологів для застосування професійних умінь у процесі виробничої практики у майбутній професійній діяльності вимагає, зокрема, грунтовної екологічної підготовки майбутнього еколога на принципах міжпредметності, інтегративності, системності й узгодження; усвідомлення майбутнім екологом своєї ролі (як фахівця, особистості); забезпечення єдності основних компонентів підготовки студентівекологів до застосування професійних умінь у майбутній професійній діяльності.

Відповідно до розробок Н. Тализіної [5], а саме моделі спеціаліста 3 позиції тих професійно значущих якостей, яких майбутній фахівець-еколог повинен набути під час навчання у ВНЗ, особливу увагу приділено компетентності, насамперед професійним (загальноінженерним та предметним), загальнонауковим, інструментальним, 
комунікаційним, соціально-особистісним. Мотиваційними якостями є: усвідомлений інтерес до дійсності, цілеспрямованість, спроможність до творчості, підвищення професійної мобільності, прагнення до професійного зростання, гнучкість. Індивідуальний стиль пізнавальної діяльності передбачає розвиток розумових здатностей, когнітивні навички (аналіз, синтез, абстракція, узагальнення, порівняння, індукція і дедукція), перцептивні навички (сприйняття, розуміння, оцінка, емпатія), рівень розвитку рефлексії (самооцінка, самоконтроль, самоаналіз), прогностичні навички (антиципація, висування гіпотез).

На нашу думку, розвивати професійні вміння можна за рахунок посилення практичної спрямованості, а саме- у процесі виробничої практики (студент застосовує знання певного курсу стосовно об'єктів, пов'язаних 3 майбутньою професійною діяльністю) та встановлення і зміцнення міждисциплінарних зв'язків (студенти застосовує набуті знання під час вивчення інших курсів у нових та застосування професійних умінь у нетипових ситуаціях).

У процесі проходження виробничої практики у студентів-екологів формується цілісне ставлення до екологічних знань, до розуміння їх приорітетності в подальшій професійній діяльності, розв'язання екологічних, економічних і соціальних проблем сучасності.

3 позиції педагогічних умов основна мета підготовки майбутніх фахівців у ВН3 полягає у формуванні та розвитку в них ключових (надпредметних) і професійних умінь, причому ефективність i результативність цих взаємопов'язаних процесів безпосередньо залежить від основних складників навчання. Отже, до основних професійних умінь, які формуються у процесі проходження студентами-екологами 3 урахуванням набутих знань під час навчання, відносимо насамперед такі:

- уміння користуватися професійною (екологічною) мовою, здатність творчо мислити, набуття дослідницького досвіду;

- уміння володіти комунікативними якостями i застосовувати їх у сфері майбутньої діяльності, а також під час самостійної роботи, у процесі колективної (групової) роботи;

- уміння застосовувати інформаційно-комунікаційні технології для самостійного здобуття необхідної інформації, презентації результатів діяльності;

- уміння користуватися вимірювальними приладами для вимірювання параметрів довкілля в майбутній професійній діяльності;

- уміння використовувати методи оцінки впливу господарської діяльності на навколишнє середовище;

- уміння розраховувати економічний збиток від забруднення навколишнього середовища підприємствами виробничої і соціальної сфери;

- уміння розробляти систему заходів, що формують екологічну політику підприємства;

- уміння розробити систему інформаційного забезпечення екологічного моніторингу на підприємстві та обгрунтувати необхідність упровадження системи екологічного контролю на підприємстві;

- уміння працювати в колективі, самостійно приймати рішення та нести за них відповідальність;

- уміння самостійно планувати й організовувати свою діяльність, зокрема експериментальну.

Виходячи 3 вище зазначеного, зауважимо, що виробнича практика відіграє важливу роль у системі вищої професійної освіти. Вона не лише сприяє формуванню 
цілісного наукового світогляду майбутніх фахівців-екологів, але й слугує фундаментом для перебудови їхньої свідомості в напрямку переходу наступних поколінь від суспільства споживання до суспільства, що формує свої стосунки 3 природою на основі ноосфер них принципів.

Підсумовуючи, зазначимо необхідність підвищення педагогічних вимог до якості професійної підготовки фахівців-екологів не лише у вищих навчальних закладах, а й в установах проходження виробничої практики студентів-екологів. Порушена проблема зумовила пошуки ефективних підходів до вдосконалення процесу виробничої практики майбутніх фахівців та орієнтацію на кінцевий результат підготовки висококваліфікованих спеціалістів. Уважаємо, що за допомогою якісної організації виробничої практики з урахуваннями педагогічних умов, іiі практичного спрямування студенти-екологи зможуть здобути не лише гідну освіту, набути професійних умінь, а й віднайти своє місце у житті, успішно вирішувати екологічні й виробничі проблеми, знаходити екологічні рішення.

\section{Література}

1. Гончаренко С. У. Український педагогічний словник / Семен Устимович Гончаренко. - К. : Либідь, 1997. - 376 с. 2. Мамрич С. М. Концептуальні засади ступеневої підготовки фахівців у навчально-науково-виробничих комплексах / С. М. Мамрич // Педагогіка і психологія професійної освіти. - 2000. - № 2. - С. 223 229. З. Ничкало Н. Г. Педагогічна книга майстра виробничого навчання: [навч.метод. посіб.] / Н. Г. Ничкало, В. О. Зайчук, Н. М. Розенберг та ін.; за ред. Н. Г. Ничкало. -[2-е вид., доп.]. - К. : Вища шк., 1994. - 76 с. 4. Помиткін Е. М. Психолого-педагогічні засади духовно орієнтованої підготовки спеціалістів науковогуманітарного профілю / Е. М. Помиткін // Педагогіка і психологія професійної освіти. - 2004. - № 6. - С. 137-144. 5. Талызина Н. Ф.Теоретические основы разработки модели специалиста / Н. Ф. Талызина. - М. : Знання, 1986. - 112 с. 6. Швед М. С.Розвиток екологічного мислення студентів університету в процесі професійної підготовки: автореф.дис. на здобуття наук. ступеня канд. пед. наук: 13.00.04 / М. С. Швед. - К., 1997. - 24 с.

УДК 37.015.31:008

Володимир Томашевський

\section{ПРОБЛЕМА ПРОФЕСІЙНОЇ ПІДГОТОВКИ МАЙБУТНІХ ДИЗАЙНЕРІВ У СИСТЕМІ ВИЩИХ НАВЧАЛЬНИХ ЗАКЛАДІВ}

Томашевський В. В. Проблема професійної підготовки майбутніх дизайнерів у системі вищих навчальних закладів.

У статті розглянуто роль естетичної культури у процесі підготовки майбутніх дизайнерів у системі вищих навчальних закладів України на сучасному етапі розвитку суспільства, а також iii структуру, надано характеристики окремих структурних компонентів естетичної культури, а саме естетичної свідомості й естетичної діяльності та їх складових категорій.

Ключові слова: професійна підготовка майбутніх дизайнерів, естетична культура, естетична свідомість, естетична діяльність.

Томашевский $\quad$ В. В. Проблема профессиональной подготовки будущих дизайнеров в системе высших учебных заведений.

В статье рассмотрена роль эстетической культуры в процессе подготовки будущих дизайнеров в системе высших учебных заведений Украины на современном 